\title{
Zastosowanie algorytmu optymalizacji wieloagentowej do automatycznej kalibracji modeli symulacyjnych
}

\begin{abstract}
W artykule przedstawiono wykorzystanie hybrydowego algorytmu optymalizacji wieloagentowej w procesie kalibracji złożowego modelu symulacyjnego. Proponowana metoda optymalizacyjna polega na uzupełnieniu algorytmu podstawowego o mechanizm zapobiegający wielokrotnemu przeszukiwaniu tych samych obszarów przestrzeni rozwiązań. Przeszukiwanie przestrzeni rozwiązań prowadzone jest ponadto na dyskretnej siatce wartości parametrów optymalizowanych, co istotnie ogranicza rozpatrywaną przestrzeń bez utraty zbieżności algorytmu. Zastosowana metoda optymalizacyjna charakteryzuje się zadowalającą efektywnością w przeszukiwaniu przestrzeni rozwiązań oraz dobrą zbieżnością.
\end{abstract}

Słowa kluczowe: wieloagentowe metody optymalizacyjne, kalibracja modelu symulacyjnego, symulacje złożowe.

\section{The application of multi-agent optimization algorithm to automatically calibrate simulation models}

\begin{abstract}
The article presents the use of a hybrid algorithm optimization of multi-agent in the process of calibrating a reservoir simulation model. The proposed optimization method consists in complementing the basic algorithm with a mechanism to prevent multiple searches of the same areas of the solution space. Moreover, searching the solution space is conducted on discrete optimized grid parameters, which significantly reduce the considered space without losing the convergence of the algorithm. The applied optimization method is characterized by satisfactory efficiency in exploring the "solution space" and good convergence.
\end{abstract}

Key words: multi-agent optimization methods, history matching, reservoir simulation.

\section{Wstęp}

Kalibracja modelu symulacyjnego jest próbą rozwiązania złożonego, źle uwarunkowanego problemu odwrotnego i polega na wprowadzeniu w modelu symulacyjnym zmian, które spowodują odtworzenie historycznych danych eksploatacyjnych. W ten sposób doprecyzowywane są parametry formacji złożowej, które w oryginalnym modelu były określone niedokładnie bądź ich wartości nie są znane. Jedną z głównych trudności jest fakt, że problem kalibracji - podobnie jak większość problemów odwrotnych - nie posiada jednoznacznego rozwiązania. Oznacza to, że na danym etapie rozpoznania złoża różne kombinacje parametrów wejściowych mogą generować zadowalającą zgodność z dany- mi obserwacyjnymi. W przypadku złóż konwencjonalnych przedstawiona niejednoznaczność modelu symulacyjnego jest zwykle eliminowana w miarę wykonywania dodatkowych pomiarów oraz trwania eksploatacji. Iteracyjny proces aktualizacji i kalibracji modelu symulacyjnego pozwala na eliminowanie kolejnych niejednoznaczności modelu, co w konsekwencji prowadzi najczęściej do uzyskania jednego wiarygodnego modelu lub rodziny rozwiązań z poprawnie oszacowanymi parametrami złożowymi.

Dla wielu parametrów złoża nie są jednak znane nawet przybliżone zakresy ich wartości (np. parametry akifera). Dodatkowym utrudnieniem jest fakt, że nieznanych parametrów 
może być nawet kilkadziesiąt, co w praktyce oznacza operowanie w kilkunastowymiarowej przestrzeni zmiennych. Mamy więc do czynienia ze złożonym układem fizycznym, definiowanym przez dużą liczbę parametrów liczbowych i opisywanym przez skomplikowany układ nieliniowych równań różniczkowych. Rozwiązanie kalibracyjnego problemu odwrotnego staje się w tej sytuacji poważnym wyzwaniem.

Jednym ze sposobów podejścia do przedstawionego problemu jest równoległe operowanie na wielu alternatywnych, wymieniających między sobą informacje rozwiązaniach $w$ celu znalezienia $w$ przestrzeni rozwiązań rozwiązania optymalnego (tzw. optymalizacyjne metody wieloagentowe). W przypadku omawianego problemu wymaga to zastosowania szeregu technik wspomagających, które pozwalają na równoczesną analizę realistycznych modeli złożowych, zawierających dane produkcyjne oraz dużą liczbę parametrów. Efektywna metoda rozwiązania kalibracyjnego problemu odwrotnego musi szybko operować w wielowymiarowej przestrzeni rozwiązań oraz skutecznie poszukiwać dobrych rozwiązań przy ograniczonej liczbie symulacji. Wybór odpowiedniej metody optymalizacji ma istotne znaczenie, gdy poszukujemy oszacowania wielu parametrów przy prawdopodobnej obecności wielokrotnych minimów lokalnych - czyli w sytuacji, która występuje w przypadku kalibrowania modeli złożowych.

$\mathrm{W}$ artykule przedstawiono zasadę działania algorytmu optymalizacyjnego oraz wyniki testów jego efektywności na przykładzie modelu symulacyjnego rzeczywistego złoża.

\section{Systemy wieloagentowe}

Przez system wieloagentowy należy rozumieć system obiektów (agentów) komunikujących się i współpracujących ze sobą w celu realizacji wspólnego celu. Jeżeli przyjmiemy, że celem tym jest znalezienie minimum pewnej funkcji i możliwe jest opisanie w sposób matematyczny sposobu komunikacji pomiędzy agentami, to w efekcie otrzymujemy wieloagentową metodę optymalizacyjną. Wśród wieloagentowych metod optymalizacji globalnej można wyróżnić liczną grupę metod inspirowanych systemami biologicznymi [1], w szczególności zachowaniem dużych zbiorowisk zwierząt. Do najczęściej stosowanych spośród nich należą algorytm mrówkowy (ACO, ang. ant colony optimization) oraz optymalizacja rojem cząstek (PSO, ang. particle swarm optimization). Zastosowanie tych metod w procesie wspomagania kalibracji modeli symulacyjnych opisano między innymi w [3-6]. Innymi metodami wieloagentowymi należącymi do wspomnianej grupy są: algorytm pszczeli (ABCA, ang. artificial bee colony algorithm), algorytm nietoperza (BA, ang. bat algorithm), algorytm świetlika (GSO, ang. glowwarm swarm optimization).

Osobną grupę algorytmów wieloagentowych tworzą metody oparte na prawach fizyki, które odpowiednio interpretowane stanowią podstawę algorytmu optymalizacyjnego.

Przykładem takiego algorytmu jest, inspirowany prawami dynamiki Newtona oraz równaniami ruchu, GSA (ang. gravitational search algorithm) [7]. W algorytmie grawitacyjnym każdy punkt w przestrzeni rozwiązań traktowany jest jak agent (możliwe rozwiązanie) posiadający masę. Parametr $m_{i}(t)$ oraz masa $M_{i}(t)$ agenta będąca miarą wartości funkcji celu w danym punkcie są wyznaczane w następujący sposób:

$$
m_{i}(t)=\frac{f i t_{i}(t)-\operatorname{worst}(t)}{\operatorname{best}(t)-\operatorname{worst}(t)}
$$

$$
M_{i}(t)=\frac{m_{i}(t)}{\sum_{j=1}^{N} m_{j}(t)}
$$

gdzie: $f t_{i}(t)$ jest wartością funkcji celu dla $i$-tego agenta w czasie $t$, natomiast $\operatorname{worst}(t)$ i best $(t)$ są odpowiednio najgorszym i najlepszym rozwiązaniem znalezionym przez algorytm.

Składowa siły wzajemnego oddziaływania pomiędzy agentami w kierunku $d$ jest wyznaczana zgodnie z poniższą formułą:

$$
F_{i j}^{d}(t)=G(t) \frac{M_{i}(t) \times M_{j}(t)}{R_{i j}+\varepsilon}\left(x_{j}^{d}(t)-x_{i}^{d}(t)\right)
$$

gdzie:

$R_{i j}=\left\|x_{i}(t) y_{j}(t)\right\|$ oznacza odległość Euklidesa między agentami , $, i " \mathrm{i}, j$ " w przestrzeni rozwiązań,

$G(t)=G_{0} e^{-\propto \frac{t}{T}}$ to zmienny współczynnik odpowiadający stałej grawitacyjnej,

$T$ - liczba iteracji,

$t$ - numer iteracji.

W efekcie $d$-ta składowa siły oddziałującej na $i$-tego agenta może być określona w następujący sposób:

$$
F_{i}^{d}(t)=\sum_{j=1, i \neq j}^{N} \operatorname{rand}_{j} F_{i j}^{d}(t)
$$

gdzie: rand $_{j}-$ liczba losowa z zakresu $[0,1]$.

W konsekwencji składowa przyspieszenie $i$-tego agenta w kierunku $d$ wynosi: $a_{i}^{d}(t)=\frac{F_{i}^{d}(t)}{M_{i}(t)}$.

Ostatecznie położenie w przestrzeni rozwiązań $i$-tego agenta w kolejnym kroku czasowym wyraża się następująco: 


$$
\begin{gathered}
v_{i}^{d}(t+1)=\operatorname{rand}_{i} \times v_{i}^{d}(t)+a_{i}^{d}(t) \\
x_{i}^{d}(t+1)=x_{i}^{d}(t)+v_{i}^{d}(t+1)
\end{gathered}
$$

gdzie $v_{i}^{d}(t)$ oraz $v_{i}^{d}(t+1)$ to zmiana położenia $i$-tego agenta w $d$-tym kierunku dla kolejnych iteracji.

Pomimo tego, że formuły (1)-(4) opisują w pewien sposób równania ruchu wynikające z praw Newtona, wielkości w nich występujące nie posiadają wynikającej z nich interpretacji fizycznej. W szczególności „masa” agenta, $M_{i}(t)$, jest wielkością bezwymiarową, co wynika wprost z jej definicji (zob. 1b). W konsekwencji „siła” oddziaływania pomiędzy agentami również nie jest wyrażona w newtonach itd. W efekcie mamy możliwość dodawania „prędkości” do „przyśpieszenia” i „przyśpieszenia” do „położenia” (formuły 4a i 4b). Powyższe równania należy więc traktować jako analogię do mechanicznych równan ruchu. W szczególności „czas" $t$ występujący w powyższych równaniach jest wielkością dyskretną i oznacza numer iteracji. Tak więc zmiana współrzędnej w kierunku $d i$-tego agenta w następnym kroku iteracji jest sumą iloczynu liczby losowej i zmiany położenia w poprzednim kroku oraz $a_{i}^{d}(t)$ - poprawki wyznaczanej na podstawie dopasowania (,masy”) agenta oraz „sily” oddziaływania z innymi agentami (zob. równania 4a, b).

Ideę metody można przedstawić w następujący sposób: każdemu agentowi przyporządkowany jest parametr „masy”, który opisuje, jak blisko poszukiwanego minimum dany agent się znajduje. Im większa „masa”, tym lepsze rozwiązanie reprezentuje agent. Przyjęcie równań ruchu Newtona do określenia sposobu poruszania się agentów w przestrzeni rozwiązań powoduje, że agent o dużej masie (a więc dobre rozwiązanie) będzie miał małe „przyśpieszenie”, a agent o małej „masie” (czyli złe rozwiązanie) - duże. Ponieważ zmiana położenia agenta jest zależna od „przyśpieszenia”, oznacza to, że dobre rozwiązanie będzie wykonywać w przestrzeni rozwiązań małe kroki (a więc przeszukiwać otoczenie już znalezionego rozwiązania), a złe rozwiązanie - duże. Taki sposób poruszania się agentów jest efektywny, ponieważ z jednej strony zapewnia przeszukiwanie obiecujących obszarów przestrzeni rozwiązań, zaś z drugiej gwarantuje eksplorację nowych kierunków poszukiwań.

\section{Wady metod wieloagentowych}

Podstawowym problemem przy stosowaniu algorytmów wieloagentowych jest zjawisko tzw. przedwczesnej zbieżności. Polega ono na tym, że algorytm po osiągnięciu dostatecznie dobrego rozwiązania nie jest w stanie znaleźć lepszego. Takie zachowanie wynika z samej idei działania omawianych metod optymalizacyjnych. W każdej z metod wieloagentowych elementy zbioru agentów, poszukując rozwiązania, są ,przyciągane" przez najlepsze znalezione dotychczas rozwiązanie. Jeśli jest ono dostatecznie dobre, to kierunki dalszych poszukiwań są zdeterminowane przez to rozwiązanie i kolejne rozwiązania „krążąa” wokół niego, co skutecznie uniemożliwia poprawienie rozwiązania. Efektywne zapobieganie przedwczesnej zbieżności polega na łączeniu $\mathrm{w}$ jednym algorytmie kilku metod optymalizacyjnych (tzw. metody hybrydowe) lub na uwzględnieniu zmienności parametrów sterujących algorytmem. Najczęściej jednak stosuje się obydwa wymienione sposoby.

Drugi problem to rozmiar przestrzeni rozwiązań, przy czym nie jest on specyficzny dla omawianych metod optymalizacyjnych. Jeżeli przyjmiemy, że dziedziną optymalizowa- nych zmiennych jest zbiór liczb rzeczywistych, to teoretycznie istnieje nieskończona liczba ich możliwych kombinacji, wśród których należy znaleźć minimum globalne. Ponadto, ze względu na stochastyczny charakter metody, istnieje realne niebezpieczeństwo wielokrotnego wyznaczania wartości funkcji celu dla tych samych lub zbyt bliskich (w sensie odległości w przestrzeni rozwiązań) punktów. Metodą pozwalającą na ograniczenie liczby możliwych kombinacji parametrów jest dyskretyzacja przestrzeni rozwiązań. Metoda ta polega na przyjęciu założenia, że wartości parametrów optymalizowanych mogą przyjmować tylko dyskretne, arbitralnie określone wartości z dozwolonego zakresu. Jeżeli dyskretyzacja przestrzeni rozwiązań będzie dostatecznie „gęsta”, to możliwe jest uzyskanie zadowalającej jakości optymalizacji dla dyskretnej, a więc ograniczonej przestrzeni rozwiązań. Przyjęcie tego założenia pozwala ponadto efektywnie kontrolować punkty, dla których wyznaczono już wartość funkcji celu, i tak sterować algorytmem, aby nie wyznaczał on jej wartości w punktach położonych zbyt „blisko” od siebie.

\section{Hybrydowy algorytm optymalizacyjny}

Proponowany algorytm numeryczny poszukuje minimum globalnego według następującego schematu:

1. Wczytanie pliku zawierającego parametry pracy programu, np. liczbę agentów, dokładność obliczeń, maksy- malną liczbę wywołań funkcji celu (symulacji), parametry metody, optymalizowane zmienne, wektory kontrolne danych obserwacyjnych, rozdzielczość siatki dyskretyzującej przestrzeń rozwiązań itd. 
2. Utworzenie dyskretnej wielowymiarowej siatki przestrzeni rozwiązań.

Pomimo tego, że optymalizowane zmienne są ciągłe w algorytmie, zastosowano dyskretną siatkę przestrzeni rozwiązań w celu efektywnego zmniejszenia jej wielkości. Zabieg taki nie zmniejsza co prawda wymiarowości przestrzeni rozwiązań, ale umożliwia istotne ograniczenie liczby możliwych kombinacji zmiennych optymalizowanych.

3. Inicjalizacja pamięci przechowującej wartości parametrów, dla których wyznaczono już wartość funkcji celu (uruchomiono symulację).

W pamięci przechowywane będą współrzędne węzłów dyskretnej siatki przestrzeni rozwiązań, dla których wyznaczono już wartość funkcji celu. Rozwiązanie takie pozwala na uniknięcie wielokrotnego rozpatrywania tej samej kombinacji parametrów optymalizowanych. Jest to istotne ze względu na możliwy długi czas trwania pojedynczej symulacji - wyznaczania wartości funkcji celu.

4. Wczytanie danych obserwacyjnych.

5. Wygenerowanie początkowej rodziny agentów (modeli symulacyjnych). Wartości parametrów identyfikujących agenty są wyznaczane dla węzłów siatki przestrzeni rozwiązań w taki sposób, aby zachowana była minimalna odległość między nimi, $D_{\text {min }}$, zdefiniowana według poniższej formuły:

$$
D_{\min }=\sqrt[p]{\frac{1}{k}}
$$

gdzie:

$p$ - wymiar przestrzeni rozwiązań,

$k-$ liczba agentów.

Liczba generowanych na tym etapie agentów wynosi $k_{0}=2 p+1$. Liczba agentów wykorzystana do wstępnego przeszukiwania przestrzeni rozwiązań została wyznaczona na podstawie testów mających na celu stwierdzenie, w jaki sposób efektywność algorytmu zależy od początkowej liczby agentów. W czasie testów prowadzonych dla liczb agentów będących wielokrotnościami wymiaru przestrzeni rozwiązań powiększonymi o jeden (tzn. $\left.k_{n}=n p+1\right)$ nie stwierdzono poprawy zbieżności algorytmu dla $n>2$.

6. Uruchomienie symulacji dla wygenerowanych agentów pokolenia początkowego (,zerowego"):

a) zapis wygenerowanych agentów w pamięci;

b) wyznaczenie wartości funkcji celu dla każdego agenta;

c) wybór $k=p+1$ najlepszych agentów (rozwiązań).
Liczbę agentów dla właściwego procesu optymalizacji przyjęto jako najmniejszą liczbę naturalną większą niż wymiar przestrzeni rozwiązań.

7. Inicjalizacja pętli optymalizacyjnej.

8. Wyznaczenie nowego położenia agentów w przestrzeni rozwiązań zgodnie z przyjętą metodologią.

Położenie każdego agenta jest obliczane na podstawie formuł (1)-(4), tzn. wyznacza się:

a) bezwymiarowe parametry wartości funkcji celu, określające jakość modelu (identyfikowanego przez kombinację parametrów optymalizowanych) w odniesieniu do najlepszego i najgorszego rozwiązania (równania 1a, 1b);

b) składowe „sił oddziaływania” pomiędzy agentami (równanie 2) oraz „wypadkową siłę” działającą na każdego agenta (równanie 3);

c) składowe „przyspieszenia” agenta, zmianę jego położenia oraz nowe współrzędne w przestrzeni rozwiązań (równania 4a, b).

9. Wyznaczenie wartości funkcji celu dla każdego elementu zbioru agentów.

10. Zapis wygenerowanych agentów w pamięci.

11. Powrót do punktu 7.

W każdym cyklu opisanym przez punkty 7-11 następuje proces wyznaczania nowego zbioru agentów, czyli modeli symulacyjnych identyfikowanych poprzez zestaw parametrów, generowanych jako współrzędne węzłów siatki przestrzeni rozwiązań. Równocześnie uruchamiany jest mechanizm kontroli sprawdzający, czy wygenerowane rozwiązanie nie znajduje się w pamięci. Jeśli tak, to proces generowania agenta trwa do momentu uzyskania unikalnego rozwiązania. Przyjęta metodologia pozwala na poprawienie zbieżności algorytmu poprzez wyeliminowanie wielokrotnego wyznaczania wartości funkcji celu w tym samym punkcie lub w zbyt bliskich punktach.

Przedstawiona procedura jest wykonywana do chwili osiągnięcia warunku zakończenia obliczeń, np. przeprowadzenia określonej liczby symulacji, iteracji czy otrzymania zadanej zgodności z danymi obserwacyjnymi.

Algorytm został zbudowany w taki sposób, aby wyeliminować konieczność udziału użytkownika w czasie procesu optymalizacji. W związku z tym program wyposażono w moduły analizy, kopiowania, przenoszenia i modyfikowania plików wsadowych, zawierających dane oraz wyniki symulacji. Po wykonaniu niezbędnych operacji program uruchamia symulator złożowy, a po zakończeniu symulacji analizuje uzyskane wyniki, porównując je z danymi obserwacyjnymi. 


\section{Test efektywności algorytmu}

\section{Testowy model symulacyjny}

Testy zbieżności zbudowanego algorytmu optymalizacyjnego przeprowadzono dla trójfazowego (ropa, woda, gaz) modelu złoża PUNQ-S3. Model symulacyjny złoża PUNQ-S3 został udostępniony przez firmę Elf dla celów testowych i jest dostępny na zasadach open source. Model składa się z 2660 bloków (siatka bloków $19 \times 28 \times 5$ ), z czego 1761 bloków jest aktywnych (model niejednorodny; średnia porowatość: 14,3\%, średnia przepuszczalność pozioma: $278,8 \mathrm{mD}$, średnia przepuszczalność pionowa: 130,6 mD). W modelu uwzględniono uskok oraz dwa aktywne akifery typu Cartera-Tracy'ego. Proces automatycznej kalibracji prowadzono dla ciśnień dennych (BHP), wykładników gazowych (WGOR) oraz wykładników wodnych (WWCT) w czasie eksploatacji złoża przez 6 odwiertów w ciągu 16 lat pracy złoża. W aplikacji wykorzystano symulator złożowy Black Oil Eclipse 100 firmy Schlumberger [2]. Na rysunku 1 przedstawiono widok 3D wykorzystanego w pracy modelu złożowego. Prowadzona analiza obejmowała kalibrację modelu dla odwiertów strefy gazowej (PRO-1, PRO-4, PRO-12) oraz ropnej (PRO-5, PRO-11 i PRO-15).

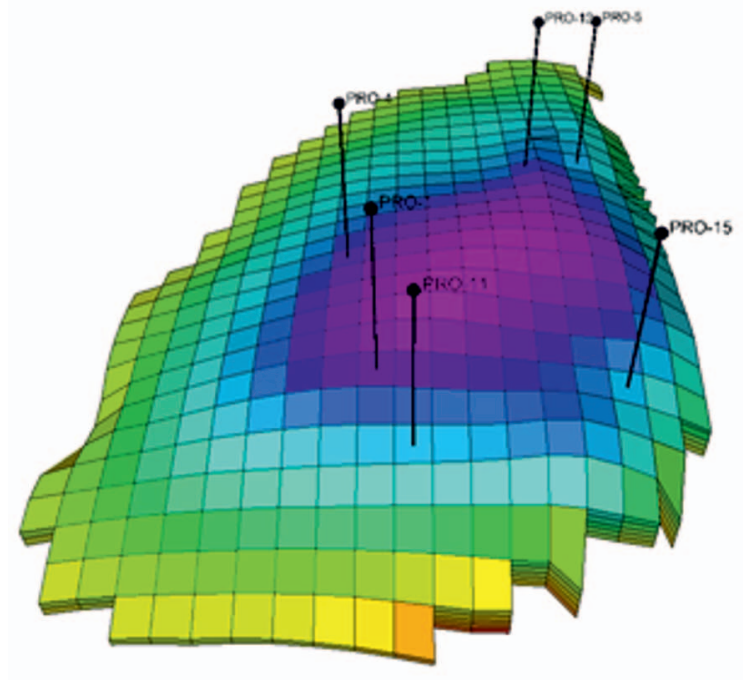

Rys. 1. Złoże PUNQ-S3. Widok 3D

\section{Funkcja celu}

Funkcję celu przyjęto w postaci średniego błędu względnego $\mathrm{w}$ formie przedstawionej poniżej:

$$
O F=\sum_{i=1}^{N} \frac{w_{i}}{n_{i}} \sum_{j=1}^{n_{i}} u_{i j}\left|\frac{O_{i j}-S_{i j}}{O_{i j}}\right|
$$

gdzie: $N$ - liczba wielkości kontrolnych, $w_{i}-$ współczynniki wagowe dla przyjętych wielkości kontrolnych, $n_{i}-$ liczba pomiarów dla $i$-tej wielkości kontrolnej, $u_{i j}$ - współczynniki wagowe dla punktów pomiarowych, $O_{i j}, S_{i j}$ - odpowiednio: dane obserwacyjne i wyniki symulacji dla $i$-tej wielkości kontrolnej i $j$-tego punktu pomiarowego.

\section{Przykład optymalizacji}

W celu zbadania skuteczności zbudowanego algorytmu wykonano testy jego zbieżności. Testy prowadzono na przykładzie modelu, w którym kalibracji podlegało 12 wybranych parametrów charakteryzujących złoże.

Jako parametry podlegające optymalizacji przyjęto głębokości kontaktów: woda-ropa oraz ropa-gaz (2 parametry), przepuszczalności i miąższości akiferów typu Cartera-Tracy'ego (2 akifery - 4 parametry), porowatość (1 parametr), współczynnik skalujący przepuszczalność poziomą w całym obszarze modelu (1 parametr), współczynnik skalujący przepuszczalność pionową w całym modelu (1 parametr), punkty końcowe przepuszczalności względnych dla wody i gazu, ( $k_{r w}, k_{r g}-2$ parametry), współczynnik skin-efektu dla odwiertów (1 parametr, jednakowy dla wszystkich kalibrowanych odwiertów).

Zestaw danych obserwacyjnych wygenerowano, uruchamiając symulację dla modelu oryginalnego złoża PUNQ-S3. Jako dane pomiarowe przyjęto wartości ciśnień dennych (WBHP), wykładników wodnych (WWCT) oraz wykładników gazowych (WGOR) dla każdego z 6 odwiertów produkcyjnych modelu w 7 punktach czasowych: 33, 1096, 2008, 2937, 4018, 4930, 6025. W efekcie model był kalibrowany na podstawie 126 punktów obserwacyjnych.

Na rysunku 2 przedstawiono, w postaci wykresu, efektywność procesu kalibracji modelu testowego. Jest ona zdefiniowana jako iloraz wartości funkcji celu dla najlepszego rozwiązania otrzymanego dla początkowej rodziny agentów przez analogiczne wartości otrzymywane w kolejnych ite-

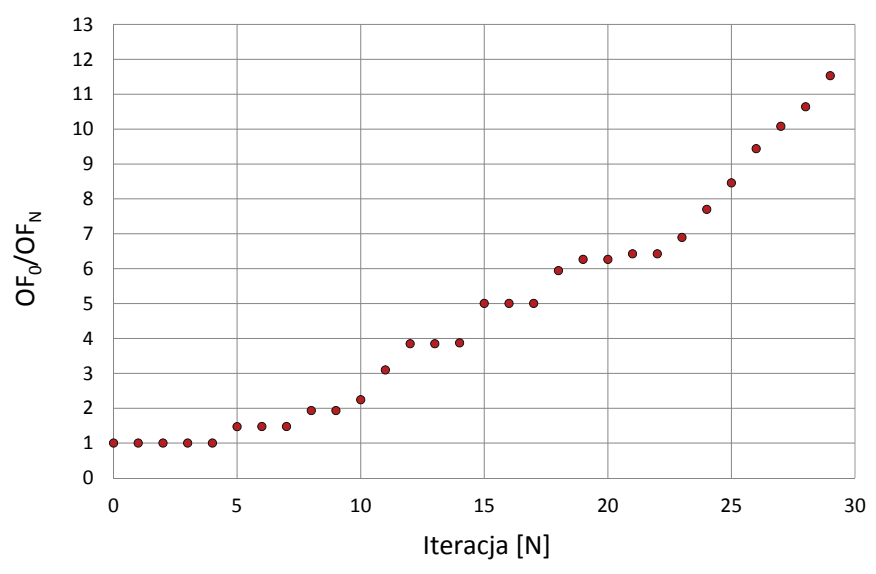

Rys. 2. Efektywność procesu optymalizacji 
racjach. Tak zdefiniowana efektywność może być interpretowana jako miara zdolności algorytmu do poprawy wyniku początkowego.

Powyższy wykres potwierdza bardzo dobrą efektywność zbudowanego algorytmu w procesie kalibracji modelu symulacyjnego. Należy zwrócić uwagę na fakt ciągłości procesu optymalizacyjnego, objawiający się brakiem długich linii poziomych na wykresie, świadczących o czasowym zatrzymaniu procesu optymalizacji.

Na rysunkach 3-8 zaprezentowano przykładowe wyniki dopasowania dla kalibrowanego modelu testowego. Przedstawione rezultaty dotyczą kalibracji modelu dla 12 parametrów optymalizacyjnych. Pomimo stosunkowo ograniczonego zbioru danych pomiarowych otrzymane dopasowania należy uznać za zadowalające. Dla ciśnień dennych (WBHP) oraz wykładników gazowych (WGOR) uzyskano bardzo dobre dopasowania danych pomiarowych do wyników symulacji. Nieco gorsze dopasowania uzyskano dla wykładników wodnych.

Rysunki 9 i 10 przedstawiają zmiany wartości wybranych parametrów w trakcie procesu optymalizacji. Przepuszczalność i miąższość akifera (model Cartera-Tracy’ego) dla agentów nr 1, 5 i 10 porównano z parametrami uzyskanymi dla najlepszego dotychczas znalezionego rozwiązania. Cechą charakterystyczną metod tego rodzaju jest to, że w miarę trwania procesu optymalizacji różnice pomiędzy wartościami parametrów dla różnych agentów stają się coraz mniejsze, co oznacza, że agenty są ,przyciągane” do znalezionego minimum. W analizowanym przypadku już po 15 iteracjach wartości przedstawionych parametrów (agenty nr 1, 5, 10 oraz najlepsze rozwiązanie) różnią się w niewielkim stopniu.

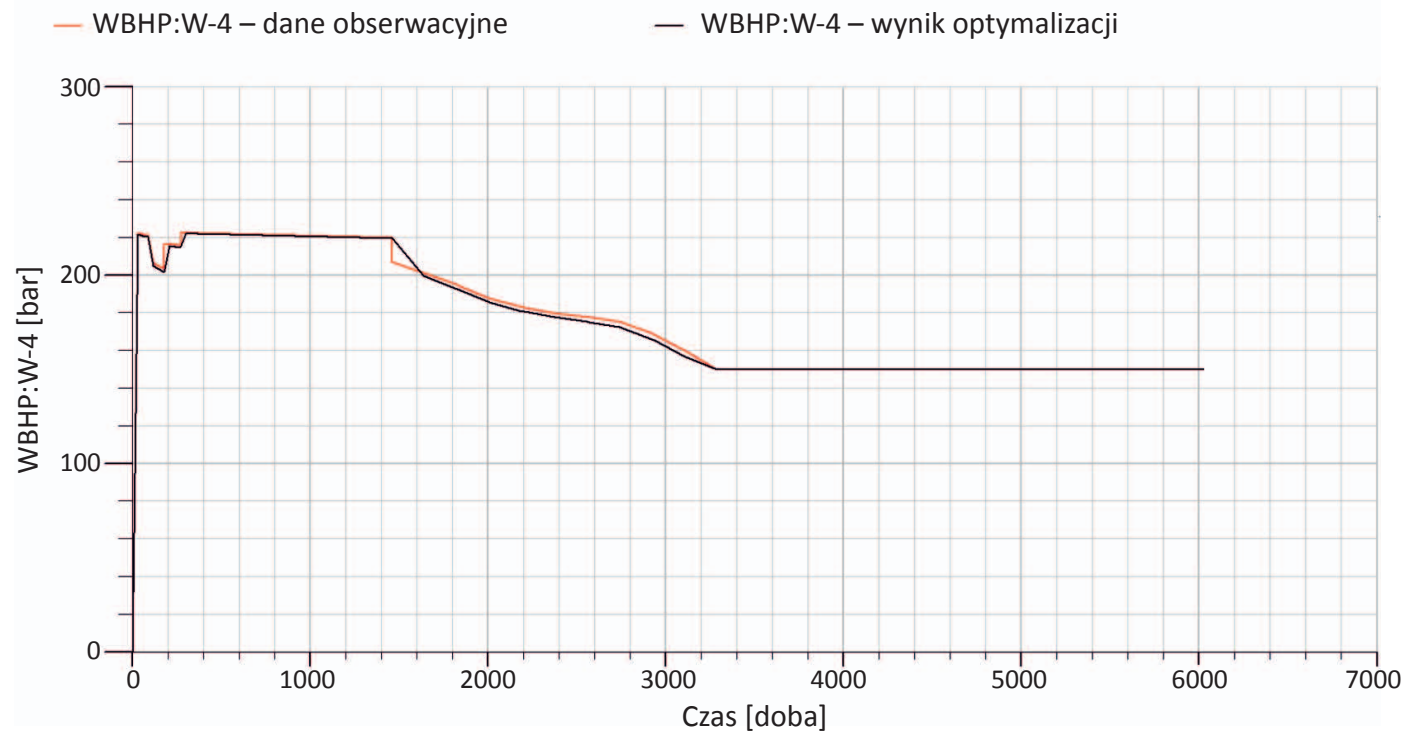

Rys. 3. Wynik dopasowania modelu. Odwiert PRO-4. Ciśnienie na spodzie odwiertu (WBHP)

- WBHP:W-5 - dane obserwacyjne $\quad-$ WBHP:W-5 - wynik optymalizacji

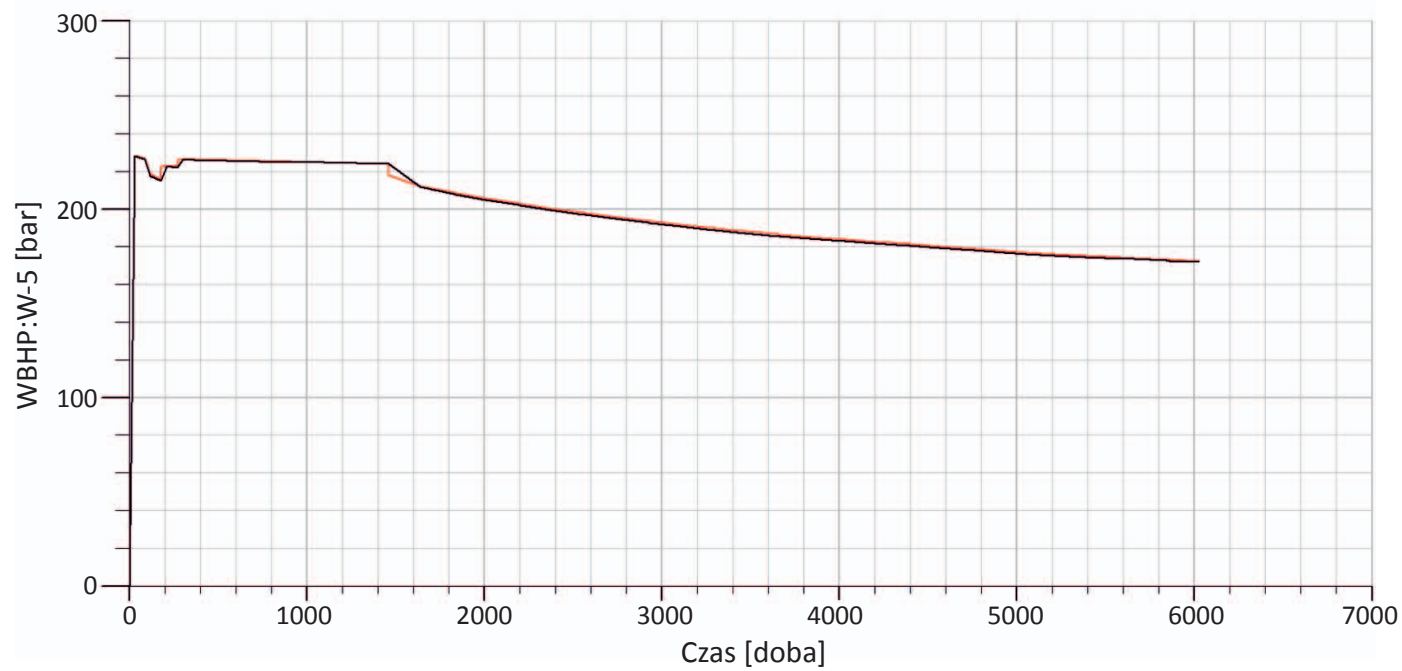

Rys. 4. Wynik dopasowania modelu. Odwiert PRO-5. Ciśnienie na spodzie odwiertu (WBHP) 
- WGOR:W-4 - dane obserwacyjne

- WGOR:W-4 - wynik optymalizacji

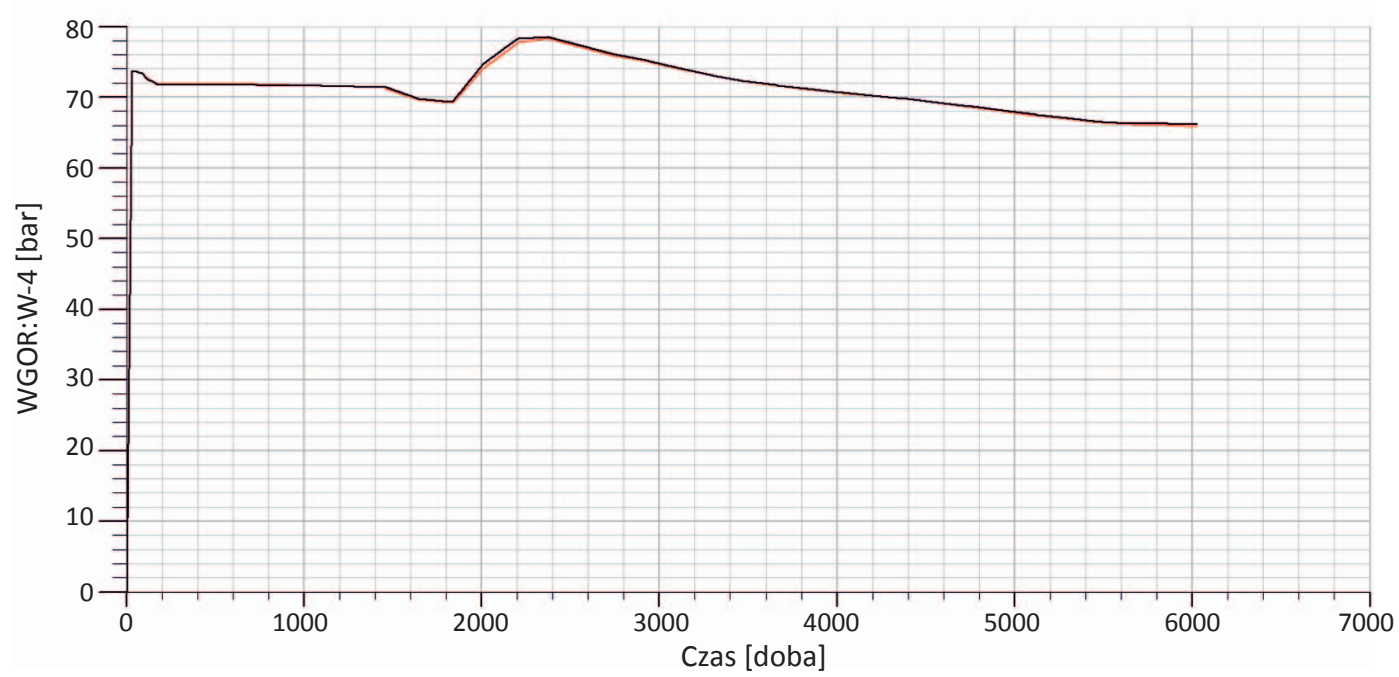

Rys. 5. Wynik dopasowania modelu. Odwiert PRO-4. Wykładnik gazowy (WGOR)

- WGOR:W-5 - dane obserwacyjne

- WGOR:W-5 - wynik optymalizacji

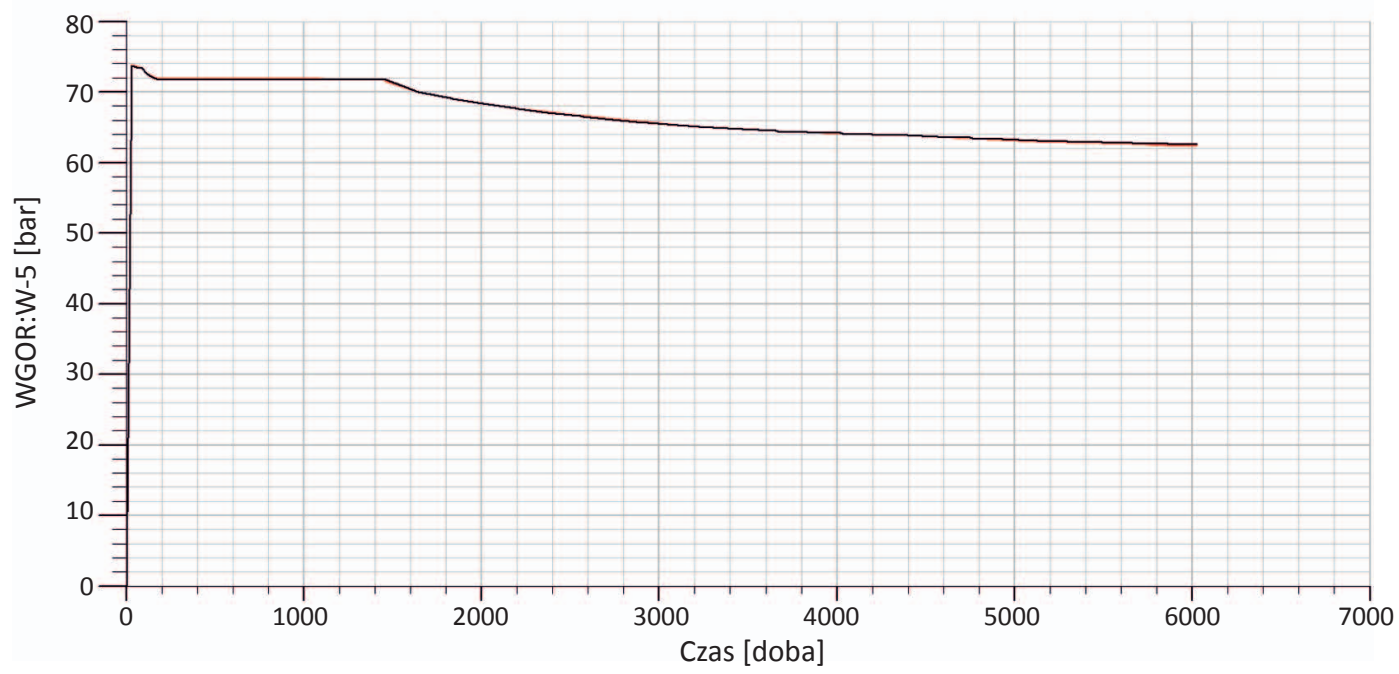

Rys. 6. Wynik dopasowania modelu. Odwiert PRO-5. Wykładnik gazowy (WGOR)

- WWCT:W-4 - dane obserwacyjne

- WWCT:W-4 - wynik optymalizacji

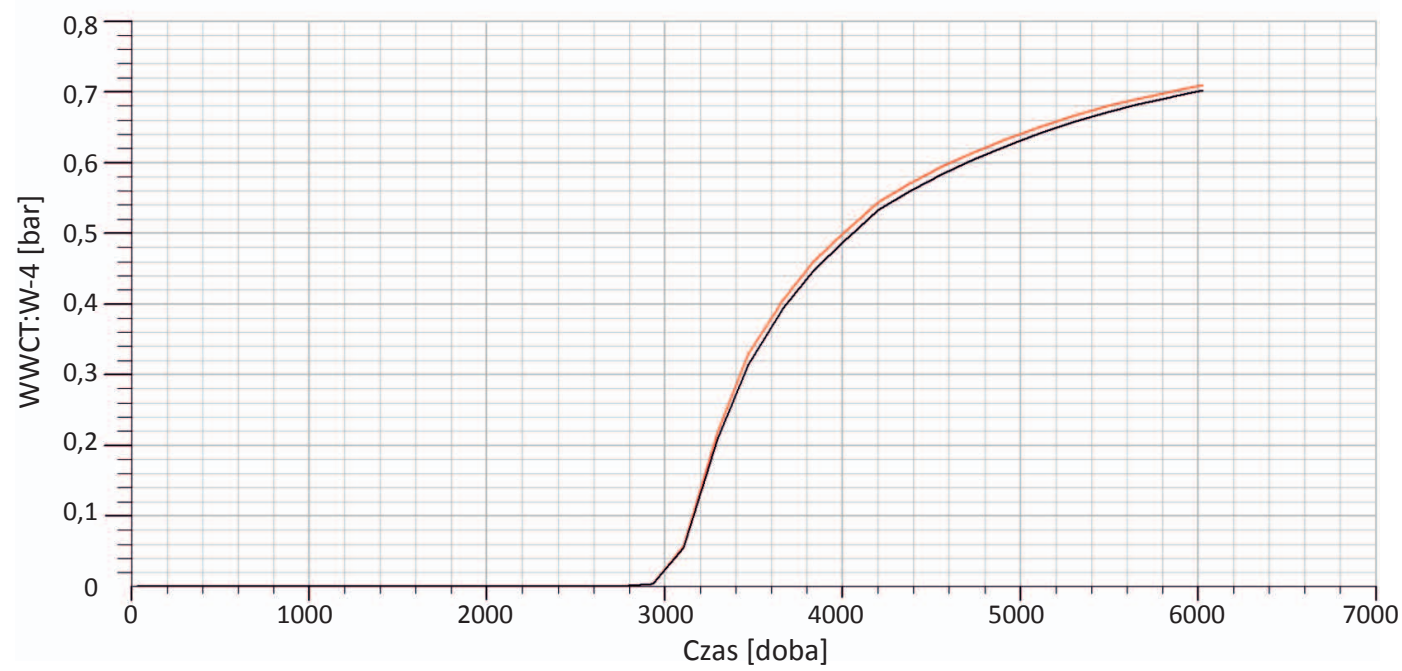

Rys. 7. Wynik dopasowania modelu. Odwiert PRO-4. Wykładnik wodny (WWCT) 


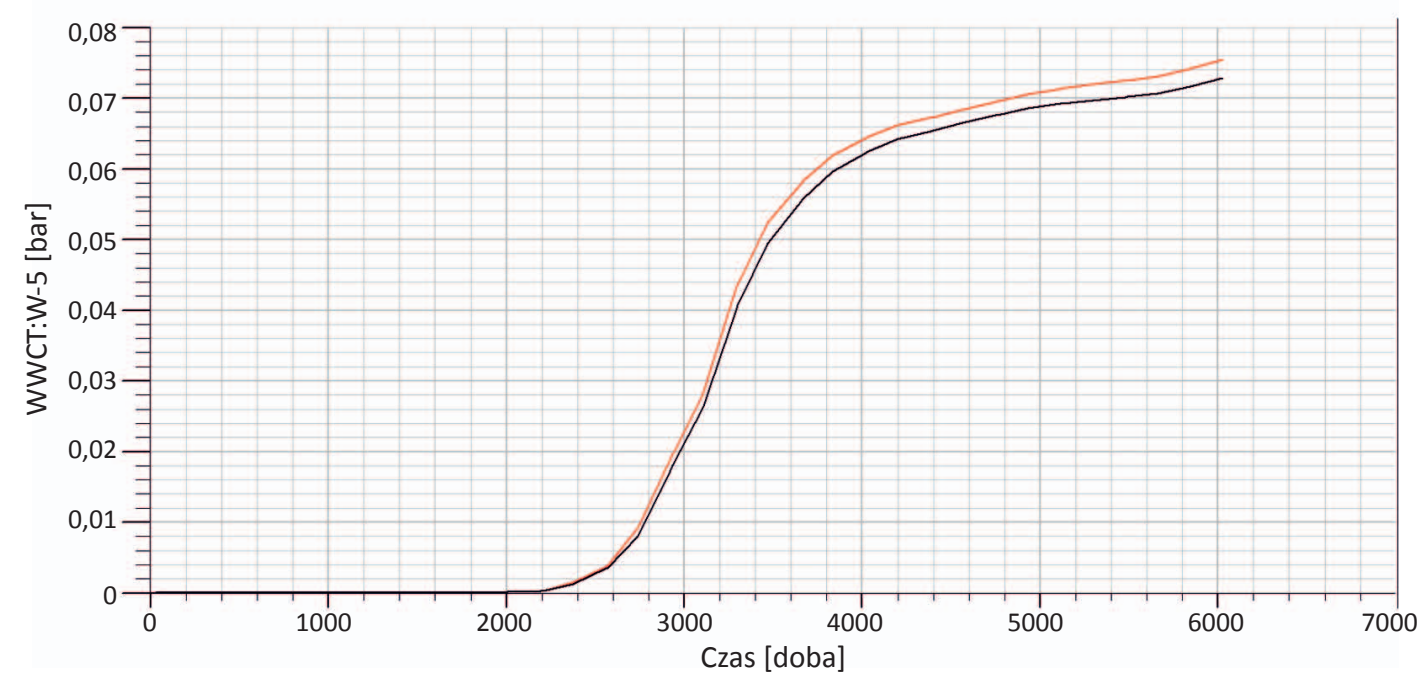

Rys. 8. Wynik dopasowania modelu. Odwiert PRO-5. Wykładnik wodny (WWCT)

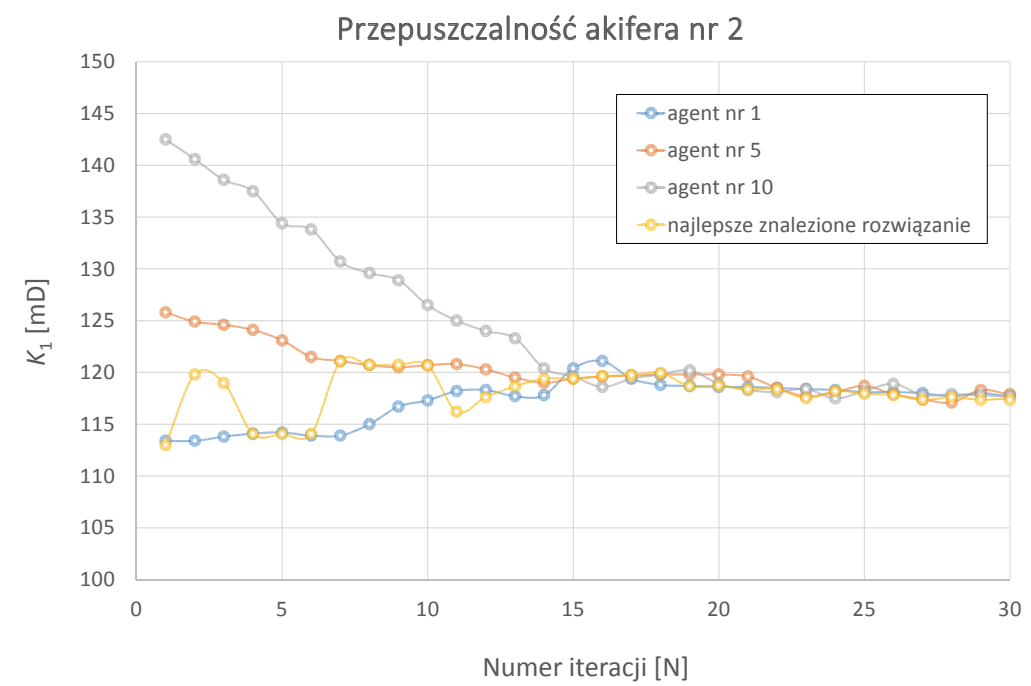

Rys. 9. Zmiana przepuszczalności akifera nr 2 dla wybranych agentów oraz najlepszego znalezionego rozwiązania w zależności od numeru iteracji, $N$

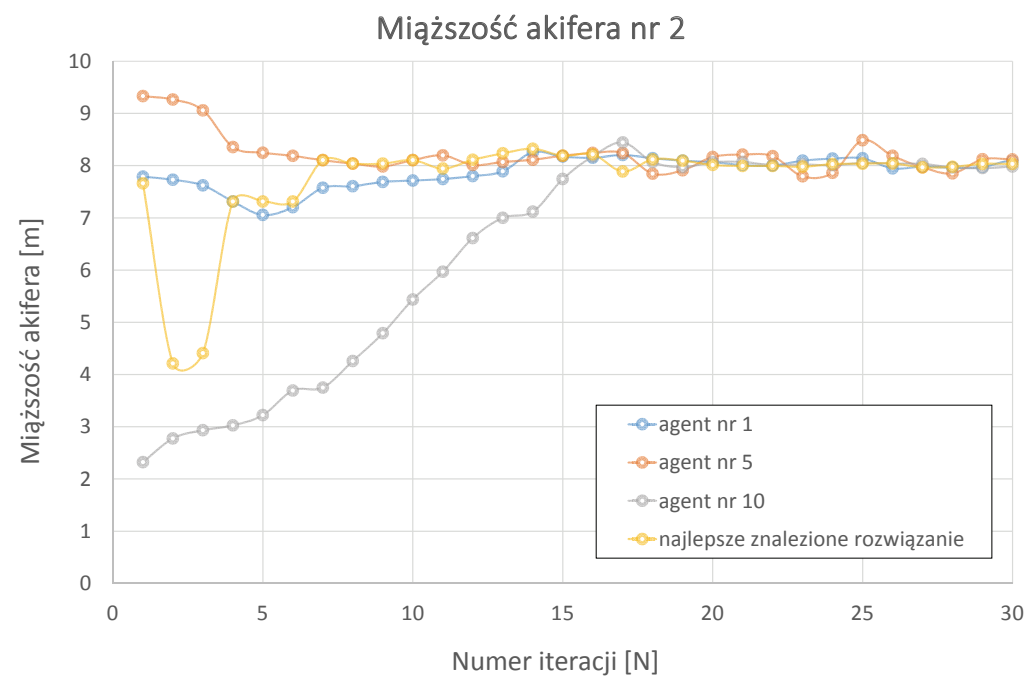

Rys. 10. Zmiana miąższości akifera nr 2 dla wybranych agentów oraz najlepszego znalezionego rozwiązania w zależności od numeru iteracji, $N$ 


\section{Podsumowanie}

Przedstawiona podstawowa metoda optymalizacyjna została uzupełniona o trzy elementy istotnie podnoszące efektywność algorytmu. Są to:

- dyskretyzacja przestrzeni rozwiązań,

- „bufor pamięci” przechowujący już wyznaczone rozwiązania oraz

- kontrola odległości między agentami na początkowym etapie działania algorytmu.

Wprowadzony mechanizm dyskretyzacji parametrów optymalizowanych istotnie ograniczył przestrzeń możliwych rozwiązań, nie powodując przy tym jednak obniżenia efektywności procesu jej przeszukiwania. Z kolei zastosowanie pamięci rozwiązań pozwoliło na wyeliminowanie wielokrotnego wyznaczania wartości funkcji celu w tych samych punktach. Ma to duże znaczenie w sytuacji, gdy czas trwania symulacji dla złóż rzeczywistych nierzadko przekracza kilka godzin.

Prosimy cytować jako: Nafta-Gaz 2016, nr 9, s. 704-712, DOI: 10.18668/NG.2016.09.04
Pewną niedogodnością stosowania proponowanej metody jest to, że jej zbieżność w dużym stopniu zależy od parametrów swobodnych wyznaczanych arbitralnie, których wartości optymalne mogą być określone wyłącznie metodą prób i błędów. Fakt ten nie ma jednak praktycznego znaczenia przy ogólnej ocenie efektywności prezentowanej metody.

Algorytmy wieloagentowe wykazują swoją efektywność w wielu dziedzinach, zarówno w przypadku rozważań teoretycznych, jak i przy rozwiązywaniu problemów o charakterze praktycznym. Ze względu na element losowości efektywnie przeszukują przestrzeń rozwiązań. Są łatwe w implementacji i bez problemu mogą być łączone zarówno ze sobą, jak i z innymi metodami optymalizacyjnymi. Powstają wtedy algorytmy hybrydowe, mające zalety wykorzystanych w nich metod. Wszystko to powoduje, że algorytmy rojowe są obiecującym kierunkiem badań nad tworzeniem coraz efektywniejszych algorytmów wspomagania procesu kalibracji modeli symulacyjnych.

Artykuł nadesłano do Redakcji 22.12.2015 r. Zatwierdzono do druku 16.07.2016 r.

\section{Literatura}

[1] Bonabeau E., Dorigo M., Theraulaz G.: Inspiration for optimization from social insect behavior. Nature 2000, vol. 406, no. 6791, s. 39-42.

[2] Eclipse 100, v 2014.1 firmy GeoQuest Schlumberger.

[3] Hajizadeh Y., Christie M., Demyanov V.: Ant colony optimization for history matching and uncertainty quantification of reservoir models. Journal of Petroleum Science and Engineering 2011, vol. 77, no. 1, s. 78-92.

[4] Kathrada M.: Uncertainty evaluation of reservoir simulation models using particle swarms and hierarchical clustering. $\mathrm{PhD}$ thesis, Institute of Petroleum Engineering, Heriot Watt University, Edinburgh, United Kingdom 2009.

[5] Łętkowski P.: Zastosowanie algorytmu mrówkowego w procesie kalibracji symulacyjnego modelu złożowego. Nafta-Gaz 2012, nr 2, s. 98-104.
[6] Łętkowski P.: Zastosowanie hybrydowej metody optymalizacji rojem czastek $w$ procesie automatycznej kalibracji modeli złożowych. Nafta-Gaz 2014, nr 11, s. 784-793.

[7] Rashedi E., Nezamabadi-pour H., Saryazdi S.: A gravitational search algorithm. Information Sciences 2009, vol. 179, no. 13, s. 2232-2248.

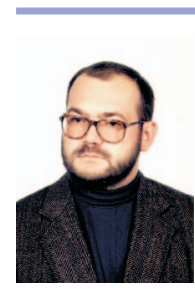

Dr inż. Piotr ŁETKOWSKI

Adiunkt w Zakładzie Symulacji Złóż Węglowodorów i Podziemnych Magazynów Gazu. Instytut Nafty i Gazu - Państwowy Instytut Badawczy ul. Lubicz 25 A

31-503 Kraków

E-mail: piotr.letkowski@inig.pl 